\title{
Stem cells and new intervention measures as emerging therapy in cardiac surgery
}

\author{
Calogera Pisano ${ }^{1}$, Paolo Nardi ${ }^{1}$, Carmela Rita Balistreri ${ }^{2}$, Claudia Altieri ${ }^{1}$, Fabio Bertoldo ${ }^{1}$, Giovanni Ruvolo ${ }^{1}$ \\ ${ }^{1}$ Cardiac Surgery Unit, Tor Vergata University Hospital, Rome, Italy \\ ${ }^{2}$ Department of Pathobiology and Medical and Forensic Biotechnologies, University of Palermo, Palermo, Italy
}

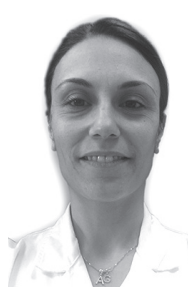

Kardiochir Torakochir Pol 2020; 17 (1): 1-7

\begin{abstract}
Cardiovascular disease (CVD) presents a great burden for elderly patients, their caregivers, and health systems. Structural and functional alterations of vessels accumulate throughout life, culminating in increased risk of developing CVD. Several inflammatory pathway are involved in vascular ageing. The growing elderly population worldwide highlights the need to understand how aging promotes CVD in order to develop new strategies to confront this challenge. In this review we analyzed the role of stem cells and new intervention measures as emerging drugs for vascular aging.
\end{abstract}

Key words: stem cell, inflammation, aging, cardiovascular diseases.

\section{Introduction}

Age dominates risk factors for cardiovascular disease (CVD) [1, 2]. Indeed, the advent of contemporary treatments for acute coronary syndromes and stroke have helped to extend life expectancy [3]. Although an enormous success from an individual perspective, the resultant demographic shift presents one of the greatest challenges for the social and health care systems worldwide [4]. The population over 65 years of age will double from $12 \%$ in 2010 to $22 \%$ in 2040 [2]. Indeed, by 2020, the number of people 60 years of age and older will surpass the number of children below 5 years of age. Although aging presents an array of disorders [5], CVD carries the greatest burden for older persons, their care givers, and health systems [6]. Coronary heart disease (CHD) associates strongly with age, and it is the leading cause of death in Europe and the United States [79]. The prevalence of CVD increases in people $>65$ years of age, especially in those $>80$ years of age, and will increase by $10 \%$ over the next 20 years [2]. From 2010 to 2030, an

\section{Streszczenie}

Choroby układu krążenia (CVD) są ogromnym obciążeniem dla osób w podeszłym wieku i ich opiekunów, a także systemów opieki zdrowotnej. Zmiany strukturalne i czynnościowe w obrębie naczyń krwionośnych zachodzą przez całe życie, co prowadzi do zwiększonego ryzyka wystąpienia CVD. W procesie starzenia się naczyń krwionośnych bierze udział kilka szlaków zapalnych. Ze względu na obserwowany na świecie wzrost liczby osób w podeszłym wieku konieczne jest zbadanie, w jaki sposób proces starzenia się wpływa na rozwój CVD. Na tej podstawie możliwe będzie opracowanie nowych strategii terapeutycznych, które pozwolą stawić czoła temu wyzwaniu. W niniejszej pracy przeglądowej przeanalizowano rolę komórek macierzystych i nowych metod interwencyjnych jako innowacyjnych sposobów niwelowania skutków procesu starzenia się naczyń krwionośnych.

Słowa kluczowe: komórki macierzyste, zapalenie, starzenie, choroby układu krążenia.

additional 27 million people will have hypertension, 8 million will have CHD, 4 million will have stroke, and 3 million will have heart failure due to the rapid accumulation of the elderly [3]. The cardiovascular system shows several modifications with advancing age [10] in all its sections. These modifications are related to the inflammatory reactions activated by several endogenous and exogenous stimuli. Stem cells emerged as new therapy to reduce the ageing related damage in the cardiovascular system. Additionally, other intervention measures have been discovered. Based on these observations, we provide an overview on emerging literature data about the role of stem cells and new intervention measures as emerging drugs for inflammation and vascular ageing in cardiac surgery.

\section{Stem cells as therapeutic option in cardiovascular disease}

Tissue loss follows heart damage in consequence of the activation of a remodeling process, in which the original 


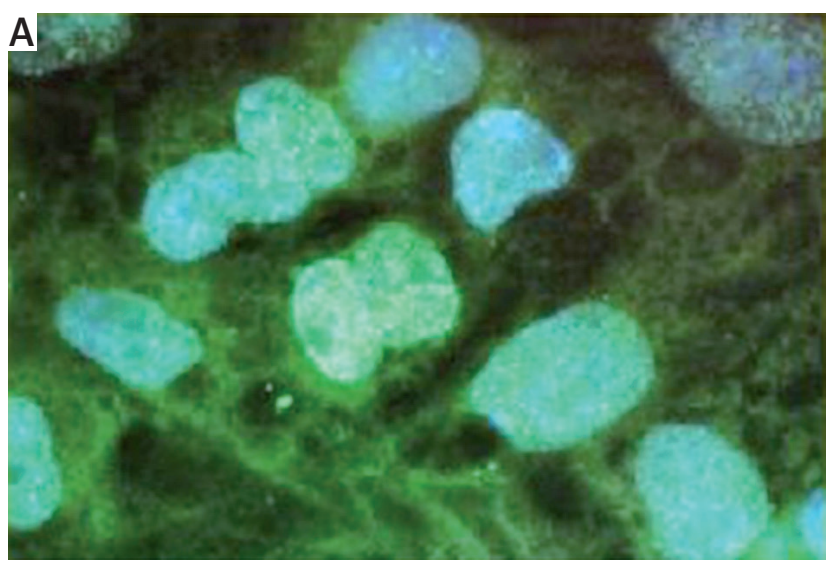

BM-MSCs

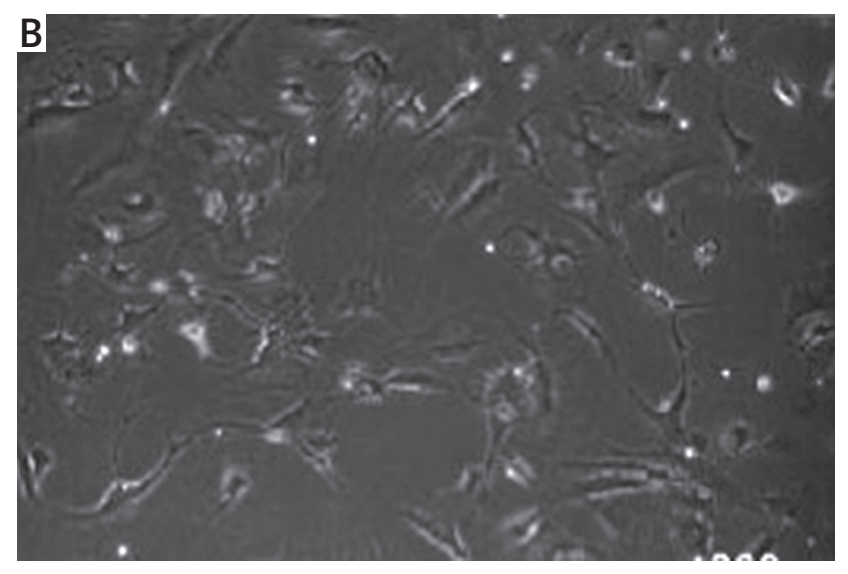

VSMC

Figure 1. A subset of bone marrow mesenchymal stem cells (BM-MSCs) have been shown to differentiate, in vitro, into vascular smooth muscle cells (VSMC) upon platelet derived growth factor $\beta$ (PDGF- $\beta$ ) stimulation

cardiac tissue is replaced by a scar [11] (Figure 1). Cardiac nonmyocyte cells, including cardiac mesenchymal stem cells (CMSCs), currently represent candidate targets for novel therapeutic strategies to counteract heart diseases [12]. Once activated, CMSCs contribute to the re-establishment of all the cardiac cell subpopulations, including cardiomyocytes [13]. Indeed, because of their plasticity, reduced immunogenicity, and the relative simplicity of isolation and culture ex vivo, CMSCs are a suitable adult stem cell population to consider for therapies based on cardiac regeneration. Recently, a significant effort has been made to enhance CMSC differentiation toward the cardiac lineage. As an example, the generation of induced pluripotent stem cells (iPS) starting from fibroblasts opened a new era for cell manipulation [14]. In 2010, leda et al. obtained for the first time induced cardiomyocytes (iCMs) from murine adult cardiac and skin fibroblasts by co-transduction of well-characterized cardiomyogenic transcription factors Gata4, Mef2c, and Tbx5 (GMT). By using this approach, the authors detected the rapid formation of cardiac troponin T positive cells (cTnT+) and the formation of contractile cells at a later time point. Once injected into the heart, GMT-transduced fibroblasts underwent in vivo reprogramming leading to the generation of new cardiomyocytes within 2 weeks [15]. Qian et al. demonstrated that nonmyocyte cells resident in the murine heart can be successfully reprogrammed in vivo into cardiomyocyte-like cells by the local delivery of GMT after coronary ligation [16]. Song et al. improved the effect of GMT transduction by adding Hand2, a transcription factor crucial for reprogramming of adult mouse cardiac fibroblasts into beating cardiac-like myocytes in vitro, through the so-called GHMT cocktail [17]. Nkx2.5, Srf, Smartcd3, Mesp1, and Myocd have also been described as other factors that can further increase fibroblast reprogramming when used in combination with GMT factors $[18,19]$. In addition to the expression of coding genes, microRNAs have also been described as a powerful tool for non-myocyte cell reprogramming. Indeed, Jayawardena and coauthors found a combination of microRNAs suitable for cardiac fibroblast reprogramming both in vitro and in vivo. This combination included miR-1, miR-133, miR208, and miR499. This set of microRNAs induced the expression of cardiac markers and also efficiently converted fibroblasts into functional cells with cardiomyocyte-like features such as the expression of ion channels, the presence of spontaneous calcium oscillations, and in vivo improved contractility and cardiac performance after injury $[20,21]$. Of note, in 2013, Nam et al. combined microRNAs with transcription factors to further enhance cell reprogramming [22]. Recently, small molecules have also been tested in reprogramming protocols to obtain iCMs or cardiovascular precursors from CMSCs. In 2012, Vecellio et al. described a novel active epigenetic cocktail (EpiC) composed of all-trans retinoic acid (ATRA); phenyl butyrate (PB), a known HDAC inhibitor; and a nitric oxide donor (diethylenetriamine/nitric oxide - DETA/NO) as a HDAC modulator [23-26], which when combined with low serum (5\% FBS) could reprogram human CMSCs into functionally competent cardiovascular precursors [27]. HDAC inhibitors such as VPA have been further used by Fu et al. in combination with three compounds, CHIR9921 (GSK3 inhibitor), RepSox (TGFßR1 inhibitor), and forskolin (adenylyl cyclase activator), to generate iCMs from fibroblasts without any transcription factor [28]. Notably, CHIR9921 is one of the three inhibitors also responsible for the "ground state" in mouse embryonic stem cells [29], and it has been recently used in combination with transcription factors and other small molecules to obtain iCMs [30]. The possibility to design an optimal culture medium to generate in vitro iCMs by a combination of small molecules [31] represents a tool of unlimited potential and a big challenge for the future. In light of this finding, Cao et al. have recently reported the reprogramming of somatic fibroblasts into cardiomyocyte-like cells by a combination of nine chemicals. The chemical cocktail opens chromatin of the cardiac developmental genes, permitting their transcription and thus the acquisition of a phenotype similar to that of embryonal cardiomyocytes [32]. A number of preclinical studies in large animal models of MI indicated significant positive effects of mesenchymal stem cell on cardiac function and on the re- 
duction of scar size [33-37]. In these studies, MSCs were administered by intravenous or intracoronary injection or through direct injection into the cardiac tissue. It is noteworthy that in some of these studies, MSCs were injected in combination with other precursor cells [38]. In fact, the stochastic lifetime accumulation of alterations consequential to DNA and mitochondrial damage, metabolic changes, oxidative stress, and inflammation, coupled with other environmental risk factors, may directly influence the homeostasis of mesenchymal niches. In 2007, APOLLO (ClinicalTrials.gov Identifier: NCT00442806_Phase 1) established the safety and feasibility of adipose-derived MSCs infused intra-coronary in patients with $\mathrm{MI}$ and characterized by ST elevation. The efficacy of the treatment was demonstrated by a significant improvement of the cardiac perfusion and a $50 \%$ reduction in scar formation after a 6-month followup [39]. Similar results were obtained by the ADVANCE (NCT01216995_Phase 2) study. However, the MyStromalCell trial (NCT01449032_Phase 2) found an increase in exercise duration, a reduction of angina, and a general improvement of the quality of life after a 6-month follow-up after injection of autologous MSCs in patients affected by ischemic cardiomyopathy. Other such trials reported positively about the overall safety and tolerance of the treatment after 13-month follow-up and a decreased number of arrhythmic events or reduced chest pain, paralleled by an improved ventricular function, in patients with acute myocardial infarction treated with bone marrow mesenchymal stem cell [40]. In the REGENT Trial (Myocardial Regeneration by Intracoronary Infusion of Selected Population of Stem Cells in Acute Myocardial Infarction), the authors compared intracoronary infusion of bone marrow (BM)-derived unselected mononuclear cells (UNSEL) and selected $\mathrm{CD} 34^{+} \mathrm{CXCR} 4^{+}$cells (SEL) in patients with acute myocardial infarction (AMI) and reduced $<40 \%$ left ventricular ejection fraction (LVEF). Two hundred patients were randomized to intracoronary infusion of UNSEL $(n=80)$ or SEL $(n=80)$ BM cells or to the control (CTRL) group without BM cell treatment. Primary endpoint: change of LVEF and volumes measured by magnetic resonance imaging before and 6 months after the procedure. After 6 months, LVEF increased by $3 \%(p=0.01)$ in patients treated with UNSEL, $3 \%$ in patients receiving SEL $(p=0.04)$ and remained unchanged in CTRL group $(p=0.73)$. There were no significant differences in absolute changes of LVEF between the groups. Absolute changes of left ventricular end-systolic volume and left ventricular end-diastolic volume were not significantly different in all groups. A significant increase of LVEF was observed only in patients treated with BM cells who had baseline LVEF < median (37\%). Baseline LVEF < median and time from the onset of symptoms to primary percutaneous coronary intervention $>$ or $=$ median were predictors of LVEF improvement in patients receiving BM cells. There were no differences in major cardiovascular events (death, re-infarction, stroke, target vessel revascularization) between groups [41]. In another randomized trial, Grajek et al. assessed change in left ventricle ejection fraction (LVEF) and myocardial perfusion in patients with acute myocardial infarction (AMI) of the anterior wall treated with bone marrow stem cells (BMSCs), compared with the control group - from baseline in the acute phase up to 12 months of follow-up. Forty-five patients were randomized $2: 1$ to the BMSC group $(n=31)$ or to the control group $(n=14)$. Bone marrow stem cells were administered into the infarct-related artery (IRA) at 4-6 days after primary $\mathrm{PCl}$. Groups were followed up with TC-99m-MIBI SPECT, radionuclide ventriculography (EF-RNV), echocardiography (ECHO), and the spiroergometric stress test. Coronary angiography was repeated after 6 months. EF-RNV did not differ significantly in both groups, but a trend towards increase in EF at 6 months and its maintenance after 12 months was noted in the BMSC group. In the rest study, perfusion index (PI) of the region supplied with blood by IRA distal to its previous occlusion (PI-IRA) improved significantly in the BMSC group at 6 months: PI-IRA at $4-6$ days vs. PI-IRA at 6 months (3.00 \pm 0.97 vs. $2.65 \pm 0.64 ; p=0.017$ ). At 12 months, PI-IRA at rest was $2.66 \pm 0.55 ; p=0.07$. A difference between BMSC and control groups in the rest study in PI-IRA was not observed. In the dipyridamole study (PI-dip), perfusion in the BMSC group was better compared with controls at 6 months ( $2.26 \pm 0.44$ vs. $2.47 \pm 0.40 ; p=0.033)$ and at 12 months ( $2.34 \pm 0.55$ vs. $2.52 \pm 0.42 ; p=0.014)$, including for the region supplied with blood by IRA (PI-IRA-dip; at 6 months $2.63 \pm 0.77$ vs. $3.06 \pm 0.46 ; p=0.021$ and at 12 months 2.71 \pm 0.63 vs. $3.15 \pm 0.51 ; p=0.001$ ). Results of LVEF, LVEDV, LVESV in ECHO and results of the spiroergometric stress test did not differ significantly between groups. Major adverse cardiac events occurred more often in the control group ( $p=0.027$ ). In conclusion, BMSC intracoronary transplantation in patients with anterior AMI did not result in increase in EF. Slight improvement of myocardial perfusion was noted in the BMSC group. This finding may indicate better microcirculation enhanced by BMSCs, but the small number of patients allows for a hypothesis rather than a final statement [42].

\section{Stem cell and tissue engineering: an advanced strategy to treat cardiovascular pathology in cardiac surgery}

At present, although the previously established treatments for cardiac and vascular disorders, such as transplantation, surgical reconstruction, use of mechanical and synthetic devices, or administration of metabolic products, are effective, they still have several constraints and complications. Hence, the development of in vitro and in vivo biomimetic constructs for specific target organs or tissues are more suitable for regeneration of damaged vessels (Figure 2). Throughout recent years many advances have been made toward using adult stem cells clinically, and this includes the development of tissue engineered vascular grafts [43] and tissue-engineered heart valves [44]. By incorporating various progenitor cells such as bone marrowderived mononuclear cells, mesenchymal stem cells, or endothelial precursor cells into biodegradable materials, 

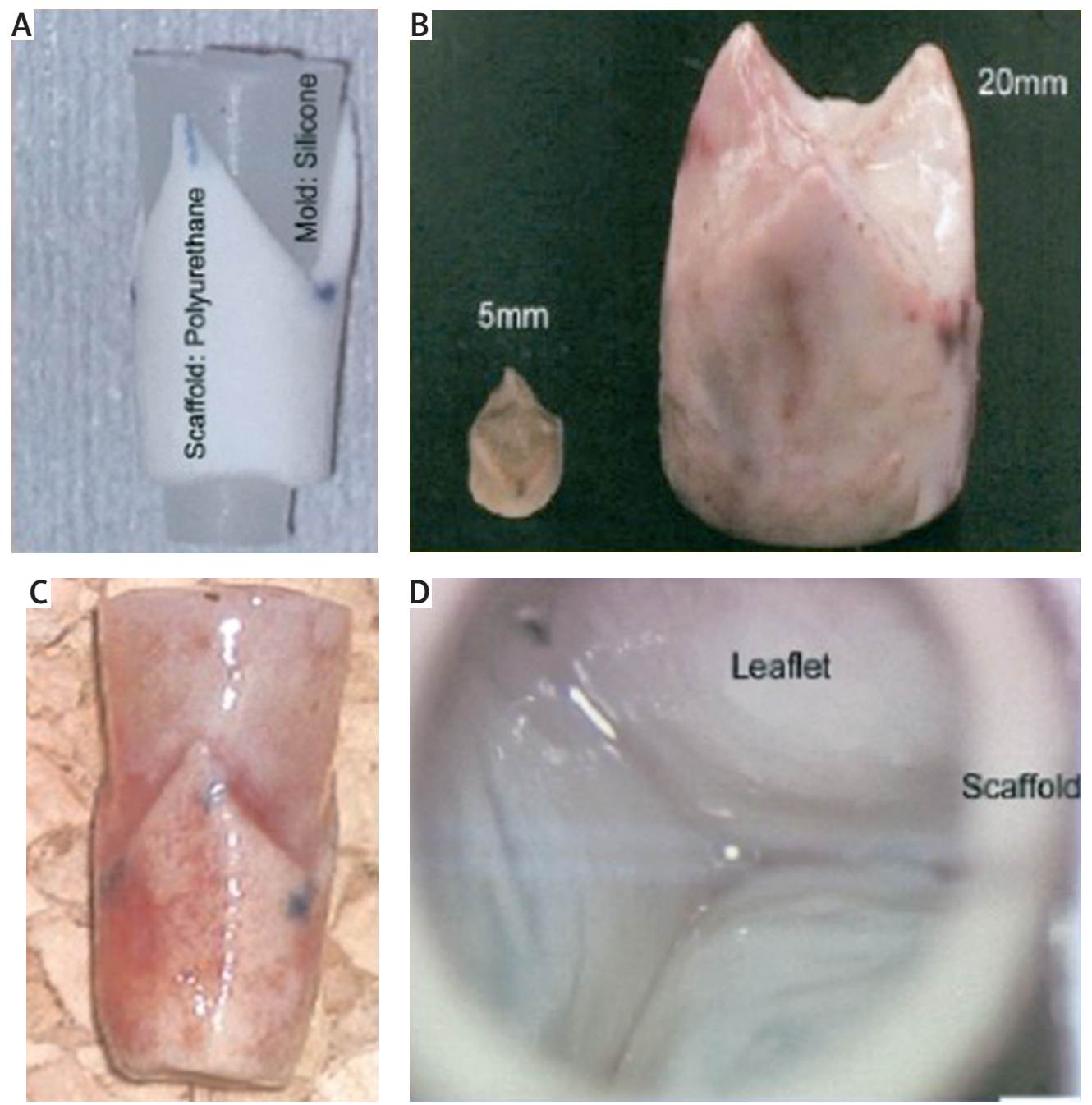

Figure 2. Development of an in vivo tissue-engineered, autologous heart valve (the biovalve)

vascular grafts and heart valves can be created that address limitations currently seen with other treatment approaches. Some of these cells have also shown the ability to initiate regenerative processes within the graft to develop tissue mimicking native arteries and valve. Tissue engineering strategies have three basic components: firstly, the cells or source which must express the appropriate genes and maintain the appropriate phenotype in order to preserve the specific function of the tissue [45]; secondly, the bioreactive agents or signals that induce cells to function; and thirdly, the scaffolds that house the cells and act as a substitute for the damaged tissue [46]. The source may be either embryonic stem cells (ESC) or adult stem cells (ASC), the scaffolds may be categorized as synthetic, biological, or composite, and the signals may include growth factors/cytokines, adhesion factors, and bioreactors [47]. Currently, downstream and upstream approaches in tissue engineering have been continuously investigated by many groups as the most promising tissue engineering approaches. The downstream approach usually employs implantation of precultured cells and synthetic scaffold complexes into the defect area. The cells or source, gener- ally isolated from host target tissues, are expanded in vitro and pre-seeded into the scaffold to provide a porous threedimensional structure that accommodates the seeded cells and forms the extracellular matrix (ECM) [48, 49]. Subsequently, multiple methods such as cell aggregation, microfabrication, cell sheeting, and cell printing are used to generate modular tissues. These are then assembled through random assembly, stacking of cell sheets, or directed assembly into engineered tissues with specific micro-architectural features. Thereafter, the engineered tissue is transplanted into the defective area. This approach allows scientists to finely transform the nanostructure of materials by balancing polymer degradation rates with ECM production and cellular infiltration which results in increased cell binding sequences, enzymatic cleavage sites, and tethering of chemoattractant molecules [49, 50]. Conversely, in the upstream approach, there are two ways to manufacture the engineered tissue: (1) cells and biomaterial scaffolds are combined and cultured until the cells fill the support structure to create an engineered tissue [51]; or (2) acellular scaffolds with incorporated biomolecules are delivered immediately after injury. The biomolecules are released from 
the scaffolds in a controlled manner, and they may recruit progenitor cells in the injured area and promote their proliferation and differentiation, eventually repairing the injured tissues [52, 53]. Tissue engineering is a promising approach that may lead to novel constructs that will satisfy this unmet need and overcome the limitations of current valve prosthetics. The tissue-engineered heart valve (TEHV) will be constructed using a combination of a porous scaffold, a cell population, and signaling factors and has the potential to provide (1) excellent hemodynamics, eliminating the need for anticoagulation therapy; (2) active tissue remodeling, preventing degeneration; and (3) growth characteristics, preventing the need for reoperation. The two primary types of valve scaffolds for the TEHV are natural scaffolds, such as decellularized tissue or biological materials, and synthetic constructs fabricated from degradable polymers [54]. Each type has inherent benefits and challenges, but decellularized heart valves are of significant interest. Decellularized heart valves are composed of biological materials that can positively impact cell differentiation and serve as building blocks during the remodeling process $[55,56]$. Additionally, decellularized valves do not necessitate complete biodegradation and often maintain the mechanical anisotropy of the native valves from which they are derived [56-59]. Decellularized heart valves have been more clinically relevant than polymeric valves thus far, as they have been implanted as stand-alone valve substitutes and as TEHVs in animals and humans, albeit with mixed results [60-68]. However, decellularized heart valves are not without their limitations. For manufacture, decellularized valves require human or animal tissue, which is limited in supply, and necessitates cryopreservation for storage. Freeze-drying of biologic heart valves has been explored to facilitate long-term storage; however, freeze-drying leads to collapse of the extracellular matrix (ECM) structure and disruption of biomolecules. Research with lycoprotectants may overcome this limitation in the future [69]. Additionally, the success of decellularized heart valves is highly reliant upon the decellularization process and the potential immune response following implantation. On the other hand, man-made scaffolds, fabricated from synthetic or biological materials, do not require donor tissue but have struggled to recreate the macro- and micro valve anatomy and mechanical anisotropy of the native valve. Fabricated scaffolds must also undergo complete biodegradation in synchrony with the production of ECM to remain functional. Fabricated or synthetic scaffolds have been used as a TEHV in animals, but have seen far less use clinically than decellularized valves. Therefore, decellularized valve scaffolds have the greatest potential for expeditious development of a TEHV due to the regulatory history, long clinical experience with homografts, as well as a deep research focus by many groups. To date, synthetic scaffolds have not been used for clinical application and still are in the research and development stage. Currently, the mechanical and biological valves are used for clinical purposes. How- ever, the mechanical prostheses have the adverse aspect of lifelong anticoagulation medication, and biological ones suffers from progressive degeneration. Biocompatible and biodegradable materials have been widely used in surgical application with neither immunogenic nor adverse side effects of degradation. Application of biocompatible scaffolds will result in a completely autologous living structure with the potential to grow and remodel. Therefore, the risk of an immunogenic response and infection is low due to the use of biodegradable materials. Shinoka et al. [70] in May 1999 developed synthetic heart valve scaffolds from a copolymer of PLA and PGA, seeded with either bone marrow cells or cells expanded from the saphenous vein harvest and conduit in 40 children with different forms of complex congenial heart valve disease. Serial post-operation investigation such as magnetic resonance imaging (MRI) and angiography represent no dilatation or even rupture while the histological evaluation image revealed calcification in these patients [70]. The application of bone marrow stem cells has been proposed recently and is still ongoing for further investigation. The harvesting is less invasive, and they grow faster than interstitial cells. However, the mechanism of differentiation is still unknown and leaves space for further survey. Neuenschwander and Hoerstrup [71] initially reported the application and implantation of a PGA scaffold seeded by autologous cells from sheep in the animal but the high stiffness of PGA and lack of mechanical properties made it unsuccessful. Later, they accepted polyhydroxyoctanoate (PHO) seeded with the autologous cells of ovine arterial. The result after 20 weeks of the implantation confirms no stenosis or thromboembolism. The experiments on natural porcine heart valve leaflets suggested that the elastic modulus and tensile strength of the valve cups are higher in the circumferential direction (collagen architecture organized direction) compared to the radial direction. Thus, the uni-axial tensile tests do not fully resemble the mechanical properties of the valve leaflets. The biaxial test is usually used to measure the circumferential and radial direction simultaneously. Stella et al. [72] investigated the biaxial time-dependent tensile behavior of a porcine heart valve including stress relaxation and strain rate under 0-60 N/m. They found that the stretch and tensile relation was insensitive to the strain rate. Their study indicates that there is no relation between the creep mechanism and the relaxation in the heart valves.

\section{Conclusions}

Regenerative medicine represents a new era in cardiac surgery. Stem cells, vascular and valve scaffolds may be the new intervention measures in the treatment of cardiovascular diseases. Other studies are necessary in order to define the therapeutic effect of stem cells and scaffolds.

\section{Disclosure}

The authors report no conflict of interest. 


\section{References}

1. North BJ, Sinclair DA. The intersection between aging and cardiovascular disease. Circ Res 2012; 110: 1097-1108.

2. Heidenreich PA, Trogdon JG, Khavjou OA, Butler J, Dracup K, Ezekowitz MD, Finkelstein EA, Hong Y, Claiborne Johnston S, Khera A, Lloyd-Jones DM, Nelson SA, Nichol G, Orenstein D, Wilson PWF, Woo YJ, American Heart Association Advocacy Coordinating Committee, Stroke Council, Council on Cardiovascular Radiology and Intervention, Council on Clinical Cardiology, Council on Epidemiology and Prevention, Council on Arteriosclerosis, Thrombosis and Vascular Biology, Council on Cardiopulmonary, Critical Care, Perioperative and Resuscitation, Council on Cardiovascular Nursing, Council on the Kidney in Cardiovascular Disease, Council on Cardiovascular Surgery and Anesthesia, and Interdisciplinary Council on Quality of Care and Outcomes Research. Forecasting the future of cardiovascular disease in the United States: a policy statement from the American Heart Association. Circulation 2011; 123: 933-944.

3. Fleg JL, Aronow WS, Frishman WH. Cardiovascular drug therapy in the elderly: benefits and challenges. Nat Rev Cardiol 2011; 8: 13-28.

4. Christensen K, Doblhammer G, Rau R, Vaupel JW. Ageing populations: the challenges ahead. Lancet 2009; 374: 1196-1208.

5. Freedman VA, Martin LG, Schoeni RF. Recent trends in disability and functioning among older adults in the United States: a systematic review. JAMA 2002; 288: 3137-3146.

6. Kovacic JC, Moreno P, Hachinski V, Nabel EG, Fuster V. Cellular senescence, vascular disease, and aging: part 2 of a 2-part review: clinical vascular disease in the elderly. Circulation 2011; 123: 1900-1910.

7. Kuller LH, Lopez OL, Mackey RH, Rosano C, Edmundowicz D, aBecker JT, Newman AB. Subclinical cardiovascular disease and death, dementia, and coronary heart disease in patients 80+ years. J Am Coll Cardiol 2016; 67: 1013-1022.

8. Newman AB, Naydeck BL, Ives DG, Boudreau RM, Sutton-Tyrrell K, O'Leary DH, Kuller LH. Coronary artery calcium, carotid artery wall thickness, and cardiovascular disease outcomes in adults 70 to 99 years old. Am J Cardiol 2008; 10: 186-192.

9. Camici GG, Savarese G, Akhmedov A, Luscher TF. Molecular mechanism of endothelial and vascular aging: implications for cardiovascular disease. Eur Heart J 2015; 36: 3392-3403.

10. van Ooij P, Garcia J, Potters WV, et al. Age-related changes in aortic 3D blood flow velocities and wall shear stress: Implications for the identification of altered hemodynamics in patients with aortic valve disease. J Magn Reson Imaging 2016; 43: 1239-1249.

11. Leask A. Potential therapeutic targets for cardiac fibrosis: TGFbeta, angiotensin, endothelin, CCN2, and PDGF, partners in fibroblast activation. Circ Res 2010; 106: 1675-1680.

12. Gourdi RG, Dimmeler E, Kohl P. Novel therapeutic strategies targeting fibroblasts and fibrosis in heart disease". Nat Rev Drug Disco 2016; 15: 620-638.

13. Zhang QJ, Chen HZ, Wang L, Liu DP, Hill JA, Liu ZP. The histone trimethyllysine demethylase JMJD2A promotes cardiac hypertrophy in response to hypertrophic stimuli in mice. J Clin Invest 2011; 121: 2447-2456.

14. Takahashi K, Yamanaka S. Induction of pluripotent stem cells from mouse embryonic and adult fibroblast cultures by defined factors. Cell 2006; 126 : 663-676.

15. leda M, Fu JD, Delgado-Olguin P, Vedantham V, Hayashi Y, Bruneau BG, Srivastava $D$. Direct reprogramming of fibroblasts into functional cardiomyocytes by defined factors. Cell 2010; 142: 375-386.

16. Qian L, Huang Y, Spencer CI, Foley A, Vedantham V, Liu L, Conway SJ, Fu JD, Srivastava D. In vivo reprogramming of murine cardiac fibroblasts into induced cardiomyocytes. Nature 2012; 485: 593-598.

17. Song K, Nam YJ, Luo X, Qi X, Tan W, Huang GN, Acharya A, Smith CL, Tallquist MD, Neilson EC, Hill JA, Bassel-Duby R, Olson EN. Heart repair by reprogramming non-myocytes with cardiac transcription factors. Nature 2012; 485: 599-604.

18. Addis RC, Ifkovits JL, Pinto F, Kellam LD, Esteso P, Rentschler S, Christoforou N, Epstein JA, Gearhart JD. Optimization of direct fibroblast reprogramming to cardiomyocytes using calcium activity as a functional measure of success. J Mol Cell Cardiol 2013; 60: 97-106.

19. Christoforou N, Chellappan M, Adler AF, Kirkton RD, Wu T, Addis RC, Bursac N, Leong KW. Transcription factors MYOCD, SRF, Mesp1 and SMARCD3 enhance the cardio-inducing effect of GATA4, TBX5, and MEF2C during direct cellular reprogramming. PLoS One 2013; 8: e63577.

20. Jayawardena TM, Egemnazarov B, Finch EA, Zhang L, Payne JA, Pandya K, Zhang Z, Rosenberg P, Mirotsou M, Dzau VJ. MicroRNA-mediated in vitro and in vivo direct reprogramming of cardiac fibroblasts to cardiomyocytes. Circ Res 2012; 110: 1465-1473.

21. Jayawardena TM, Finch EA, Zhang L, Zhang H, Hodgkinson CP, Pratt RE, Rosenberg PB, Mirotsou M, Dzau VJ. MicroRNA induced cardiac reprogramming in vivo: evidence for mature cardiac myocytes and improved cardiac function. Circ Res 2015; 116: 418-424.

22. Nam YJ, Song K, Luo X, Daniel E, Lambeth K, West K, Hill JA, DiMaio JM, Baker LA, Bassel-Duby R, Olson EN. Reprogramming of human fibroblasts toward a cardiac fate. Proc Natl Acad Sci USA 2013; 110: 5588-5593.

23. Illi B, Colussi C, Grasselli A, Farsetti A, Capogrossi MC, Gaetano C. NO sparks off chromatin: tales of a multifaceted epigenetic regulator. Pharmacol Ther 2009; 123: 344-352.

24. Illi B, Dello Russo C, Colussi C, Rosati J, Pallaoro M, Spallotta F, Rotili D, Valente S, Ragone G, Martelli F, Biglioli P, Steinkuhler C, Gallinari P, Mai A, Capogrossi MC, Gaetano C. Nitric oxide modulates chromatin folding in human endothelial cells via protein phosphatase $2 \mathrm{~A}$ activation and class II histone deacetylases nuclear shuttling. Circ Res 2008; 102: 51-58.

25. Spallotta F, Rosati J, Straino S, Nanni S, Grasselli A, Ambrosino V, Rotili D, Valente S, Farsetti A, Mai A, Capogrossi MC, Gaetano C, Illi B. Nitric oxide determines mesodermic differentiation of mouse embryonic stem cells by activating class Ila histone deacetylases: potential therapeutic implications in a mouse model of hindlimb ischemia. Stem Cells 2010; 28: 431-442.

26. Rosati J, Spallotta F, Nanni S, Grasselli A, Antonini A, Vincenti S, Presutti C, Colussi C, D’Angelo C, Biroccio A, Farsetti A, Capogrossi MC, Illi B, Gaetano C. Smad-interacting protein-1 and microRNA 200 family define a nitric oxidedependent molecular circuitry involved in embryonic stem cell mesendoderm differentiation. Arterioscler Thromb Vasc Biol 2011; 31: 898-907.

27. Vecellio M, Meraviglia V, Nanni S, Barbuti A, Scavone A, DiFrancesco D, Farsetti A, Pompilio G, Colombo Gl, Capogrossi MC, Gaetano C, Rossini A. In vitro epigenetic reprogramming of human cardiac mesenchymal stromal cells into functionally competent cardiovascular precursors. PLoS One 2012; 7: e51694.

28. Fu JD, Srivastava D. Direct reprogramming of fibroblasts into cardiomyocytes for cardiac regenerative medicine. Circ J 2015; 79: 245-254.

29. Fu Y, Huang C, Xu X, Gu H, Ye Y, Jiang C, Qiu Z, Xie X. Direct reprogramming of mouse fibroblasts into cardiomyocytes with chemical cocktails. Cell Res 2015; 25: 1013-1024.

30. Ying QL, Wray J, Nichols J, Batlle-Morera L, Doble B, Woodgett J, Cohen P, Smith A. The ground state of embryonic stem cell self-renewal. Nature 2008; 453: 519-523.

31. Wang K, Liu F, Zhou LY, Long B, Yuan SM, Wang Y, Liu CY, Sun T, Zhang XJ, Li PF. The long non- coding RNA CHRF regulates cardiac hypertrophy by targeting miR-489. Circ Res 2014; 114: 1377-1388.

32. Cao N, Huang Y, Zheng J, Spencer Cl, Zhang Y, Fu JD, Nie B, Xie M, Zhang M, Wang H, Ma T, Xu T, Shi G, Srivastava D, Ding S. Conversion of human fibroblasts into functional cardiomyocytes by small molecules. Science 2016; 352 : 1216-1220.

33. Amado LC, Saliaris AP, Schuleri KH, St John M, Xie JS, Cattaneo S, Durand DJ, Fitton T, Kuang JQ, Stewart G, Lehrke S, Baumgartner WW, Martin BJ, Heldman AW, Hare JM. Cardiac repair with intramyocardial injection of allogeneic mesenchymal stem cells after myocardial infarction. Proc Natl Acad Sci USA 2005; 102: 11474-11479.

34. Qi CM, Ma GS, Liu NF, Shen CX, Chen Z, Liu XJ, Hu YP, Zhang XL, Teng GJ, Ju SH, Ma M, Tang YL. Transplantation of magnetically labeled mesenchymal stem cells improves cardiac function in a swine myocardial infarction model. Chin Med J 2008; 121: 544-550.

35. Quevedo HC, Hatzistergos KE, Oskouei BN, Feigenbaum GS, Rodriguez JE, Valdes D, Pattany PM, Zambrano JP, Hu Q, McNiece I, Heldman AW, Hare JM. Allogeneic mesenchymal stem cells restore cardiac function in chronic ischemic cardiomyopathy via trilineage differentiating capacity. Proc Natl Acad Sci USA 2009; 106: 14022-14027.

36. Hatzistergos KE, Hare JM. Murine models demonstrate distinct Vasculogenic and cardiomyogenic cKit + Lineages in the heart". Circ Res 2016; 118: 382-387.

37. Hatzistergos KE, Quevedo H, Oskouei BN, Hu Q, Feigenbaum GS, Margitich IS, Mazhari R, Boyle AJ, Zambrano JP, Rodriguez JE, Dulce R, Pattany PM, Valdes D, Revilla C, Heldman AW, McNiece I, Hare JM. Bone marrow mesenchymal stem cells stimulate cardiac stem cell proliferation and differentiation. Circ Res 2010; 107: 913-922.

38. Avolio E, Gianfranceschi G, Cesselli D, Caragnano A, Athanasakis E, Katare R, Meloni M, Palma A, Barchiesi A, Vascotto C, Toffoletto B, Mazzega E, Finato N, Aresu G, Livi U, Emanueli C, Scoles G, Beltrami CA, Madeddu P, Beltrami AP. Ex vivo molecular rejuvenation improves the therapeutic activity of senes- 
cent human cardiac stem cells in a mouse model of myocardial infarction. Stem Cells 2014; 32: 2373-2385

39. Houtgraaf JH, den Dekker WK, van Dalen BM, Springeling T, de Jong R, van Geuns RJ, Geleijnse ML, Fernandez-Aviles F, Zijlsta F, Serruys PW, Duckers HJ. First experience in humans using adipose tissue-derived regenerative cells in the treatment of patients with ST-segment elevation myocardial infarction. J Am Coll Cardiol 2012; 59: 539-540.

40. Karantalis V, DiFede DL, Gerstenblith G, Pham S, Symes J, Zambrano JP, Fishman J, Pattany P, McNiece I, Conte J, Schulman S, Wu K, Shah A, Breton E, Davis-Sproul J, Schwarz R, Feigenbaum G, Mushtaq M, Suncion VY, Lardo AC, Borrello I, Mendizabal A, Karas TZ, Byrnes J, Lowery M, Heldman AW, Hare JM. Autologous mesenchymal stem cells produce concordant improvements in regional function, tissue perfusion, and fibrotic burden when administered to patients undergoing coronary artery bypass grafting: the prospective randomized study of mesenchymal stem cell therapy in patients undergoing cardiac surgery (PROMETHEUS) trial. Circ Res 2014; 114: 1302-1310.

41. Tendera M, Wojakowski W, Ruzyłło W, Chojnowska L, Kepka C, Tracz W, Musiałek P, Piwowarska W, Nessler J, Buszman P, Grajek S, Breborowicz P, Majka M, Ratajczak MZ; REGENT Investigators. Intracoronary infusion of bone marrow-derived selected CD34+CXCR4+ cells and non-selected mononuclear cells in patients with acute STEMI and reduced left ventricular ejection fraction: results of randomized, multicentre Myocardial Regeneration by Intracoronary Infusion of Selected Population of Stem Cells in Acute Myocardial Infarction (REGENT) Trial. Eur Heart J 2009; 30: 1313-1321.

42. Grajek S, Popiel M, Gil L, Breborowicz P, Lesiak M, Czepczyński R, Sawiński K, Straburzyńska-Migaj E, Araszkiewicz A, Czyz A, Kozłowska-Skrzypczak M, Komarnicki $M$. Influence of bone marrow stem cells on left ventricle perfusion and ejection fraction in patients with acute myocardial infarction of anterior wall: randomized clinical trial: Impact of bone marrow stem cell intracoronary infusion on improvement of microcirculation. Eur Heart J 2010; 31: 691-702.

43. Wang Y, Yin P, Bian GL, Huang HY, Shen H, Yang JJ, Yang ZY, Shen ZY. Thecombination of stem cells and tissue engineering: an advanced strategy for blood vessels regeneration and vascular disease treatment. Stem Cell Res Ther 2017; 8: 194.

44. VeDepo MC, Detamore MS, Hopkins RA, Converse GL. Recellularization of decellularized heart valves: Progress toward the tissue-engineered heart valve". J Tissue Eng 2017; 25: 2041731417726327.

45. Kim BS, Mooney DJ. Development of biocompatible synthetic extracellular matrices for tissue engineering. Trends Biotechnol 1998; 16: 224-230.

46. Demirbag B, Huri PY, Kose GT, Buyuksungur A, Hasirci V. Advanced cell therapies with and without scaffolds. Biotechnol J 2011; 6: 1437-1453.

47. Flanagan TC, Pandit A. Living artificial heart valve alternatives: a review. Eur Cell Mater 2003; 6: 28-45.

48. Ji W, Sun Y, Yang F, van den Beucken JJ, Fan M, Chen Z, Jansen JA. Bioactive electrospun scaffolds delivering growth factors and genes for tissue engineering applications. Pharm Res 2011; 28: 1259-1272.

49. Ma Z, Kotaki M, Inai R, Ramakrishna S. Potential of nanofiber matrix as tissue-engineering scaffolds. Tissue Eng 2005; 11: 101-109.

50. Nichol JW, Khademhosseini A. Modular tissue engineering: engineering biological tissues from the bottom up. Soft Matter 2009; 5: 1312-1319.

51. Rizzi SC, Ehrbar M, Halstenberg S, Raeber GP, Schmoekel HG, Hagenmüller H, Müller R, Weber FE, Hubbell JA. Recombinant protein-co-peg networks as cell-adhesive and proteolytically degradable hydrogel matrixes. Part II: biofunctional characteristics. Biomacromolecules 2006; 7: 3019-3029.

52. Brody S, Pandit A. Approaches to heart valve tissue engineering scaffold design. J Biomed Mater Res B Appl Biomater 2007; 83: 16-43.

53. Li F, Li W, Johnson S, Ingram D, Yoder M, Badylak S. Low-molecular-weight peptides derived from extracellular matrix as chemoattractants for primary endothelial cells. Endothelium 2004; 11: 199-206.

54. Iop L, Renier V, Naso F, Piccoli M, Bonetti A, Gandaglia A, Pozzobon M, Paolin A, Ortolani F, Marchini M, Spina M, De Coppi P, Sartore S, Gerosa G. The influence of heart valve leaflet matrix characteristics on the interaction be- tween human mesenchymal stem cells and decellularized scaffolds. Biomaterials 2009; 30: 4104-4116.

55. Converse GL, Armstrong M, Quinn RW, Buse EE, Cromwell ML, Moriarty SJ, Lofland GK, Hilbert SL, Hopkins RA. Effects of cryopreservation, decellularization and novel extracellular matrix conditioning on the quasi-static and time- dependent properties of the pulmonary valve leaflet. Acta Biomater 2012; 8: 2722-2729.

56. Korossis SA, Booth C, Wilcox HE, Watterson KG, Kearney JN, Fisher J, Ing ham $\mathrm{E}$. Tissue engineering of cardiac valve prostheses II: biomechanical characterization of decellularized porcine aortic heart valves. J Heart Valve Dis 2002; 11: 463-471

57. Liao J, Joyce EM, Sacks MS. Effects of decellularization on the mechanical and structural properties of the porcine aortic valve leaflet. Biomaterials 2008; 29: 1065-1074.

58. VeDepo MC, Buse EE, Quinn RW, Williams TD, Detamore MS, Hopkins RA, Converse GL. Species-specific effects of aortic valve decellularization. Acta Biomater 2017; 50: 249-258.

59. Argento G, Simonet M, Oomens CW, Baaijens FP. Multi-scale mechanical characterization of scaffolds for heart valve tissue engineering. J Biomech 2012; 45: 2893-2898.

60. Simon P, Kasimir MT, Seebacher G, Weigel G, Ullrich R, Salzer-Muhar U, Rieder E, Wolner E. Early failure of the tissue engineered porcine heart valve SYNERGRAFT in pediatric patients. Eur J Cardiothorac Surg 2003; 23: 1002-1006.

61. Dohmen PM, Hauptmann S, Terytze A, Konertz WF. In-vivo repopularization of a tissue-engineered heart valve in a human subject. J Heart Valve Dis 2007; 16: 447-449.

62. Dohmen PM, Lembcke A, Holinski S, Kivelitz D, Braun JP, Pruss A, Konertz W. Mid-term clinical results using a tissue-engineered pulmonary valve to reconstruct the right ventricular outflow tract during the Ross procedure. Ann Thorac Surg 2007; 84: 729-736.

63. Dohmen PM, Lembcke A, Holinski S, Pruss A, Konertz W. Ten years of clinical results with a tissue-engineered pulmonary valve. Ann Thorac Surg 2011; 92 1308-1314.

64. Dohmen PM, Lembcke A, Hotz H, Kivelitz D, Konertz WF. Ross operation with a tissue-engineered heart valve. Ann Thorac Surg 2002; 74: 1438-1442.

65. Dohmen PM. Clinical results of implanted tissue engineered heart valves. HSR Proc Intensive Care Cardiovasc Anesth 2012; 4: 225-231.

66. Ouinn R, Hilbert S, Converse G, Bert AA, Buse EE, Drake WB, Armstrong M, Moriaty SJ, Lofland GK, Hopkins RA. Enhanced autologous re-endothelialization of decellularized and extracellular matrix conditioned allografts implanted into the right ventricular outflow tracts of juvenile sheep. Cardiovasc Eng Techn 2012; 3: 217-227.

67. Quinn RW, Hilbert SL, Bert AA, Drake BW, Bustamante JA, Fenton JE, Moriarty SJ, Neighbors SL, Lofland GK, Hopkins RA. Performance and morphology of decellularized pulmonary valves implanted in juvenile sheep. Ann Thorac Surg 2011; 92: 131-137.

68. Wang S, Goecke T, Meixner C, Haverich A, Hilfiker A, Wolkers WF. Freeze-died heart valve scaffolds. Tissue Eng Part C Methods 2012; 18: 517-525.

69. Kluin J, Talacua H, Smits Al, Emmert MY, Brugmans MC, Fioretta ES, Dijkman PE, Söntjens SH, Duijvelshoff R, Dekker S, Janssen-van den Broek MW, Lintas V, Vink A, Hoerstrup SP, Janssen HM, Dankers PY, Baaijens FP, Bouten $C V$. In situ heart valve tissue engineering using a bioresorbable elastomeric implant - from material design to 12 months follow-up in sheep. Biomaterials 2017; 125: 101-117.

70. Shinoka T, ShumTim D, Ma PX, Tanel RE, Langer R, Vacanti JP, Mayer Jr. JE. Tissue-engineered heart valve leaflets: does cell origin affect outcome? Circulation 1997; 96; 102-107.

71. Neuenschwander S, Hoerstrup SP. Heart valve tissue engineering. Transpl Immunol 2004; 12: 359-365.

72. Stella JA, Liao J, Sacks MS. Time-dependent biaxial mechanical behavior of the aortic heart valve leaflet. J Biomech 2007: 40: 3169-3177. 